\title{
Time, Work, and Law: a New Zealand Perspective
}

\author{
AMANDA REILLY*
}

\begin{abstract}
New Zealand is popularly perceived as a laid back place where individuals might choose to live to enjoy a slower paced life style. However, the reality is that New Zealanders work some of the longest days and the most hours per annum in the OECD.

In this article, it is argued that existing legal mechanisms for limiting work time are rooted in increasingly obsolete work patterns premised on strong unions and a workforce of permanent full-time employees who are supported by an unpaid female workforce who carry the burden of reproductive care work. However, in New Zealand, as elsewhere, these legal mechanisms have been undermined by de-unionisation, the emergence of precarious work and the growing numbers of women in the workforce. Consequently, the ability of workers to limit their work time has been significantly compromised. In the final part of the article, it is suggested that a Guaranteed Basic Income could, given the changing nature of work, be a more effective and flexible mechanism for controlling working time than current law.
\end{abstract}

\section{Introduction}

New Zealand claims to be the first country in the world to introduce the eight hour working day dating from 1840 when carpenter Samuel Parnell went on strike insisting he would only work eight hours a day on a carpentry job. He famously said

There are twenty-four hours per day given us, eight of these should be for work, eight for sleep, and the remaining eight for recreation and in which for men to do what little things they want to do for themselves.

To this day, New Zealand is popularly perceived as a laid back place where individuals might choose to live to enjoy a slower paced life style. However, the reality is that New Zealanders work some of the longest days and the most hours per annum in the OECD. ${ }^{1}$ One survey indicates that $40 \%$ of New Zealanders have some or a lot of difficulty getting the work life balance they want and $46 \%$ experience some degree of worklife conflict. ${ }^{2}$ A recent Department of Labour study into those who work long hours reported that $22.68 \%$ of the total workforce work long hours (defined as 50 hours per week.) Notably, the longest working hours are found among the poorest working people with income distribution skewing downwards among those working over 60 hours a week. ${ }^{3} 20.1 \%$ of those working 60 or more hours a week report themselves as dissatisfied or very dissatisfied with their work-life balance. ${ }^{4}$

Historically, legal norms and mechanisms have operated to allow people to exercise control over their time by limiting working hours. This article proposes that a Guaranteed Basic Income (BI) might be a better option than existing labour and employment law mechanisms (i.e. informal workplace norms, collective

\footnotetext{
* Lecturer in Law, School of Accounting and Commercial Law, Victoria University of Wellington

${ }^{1}$ Organisation for Economic Co-Operation and Development "Clocking In and Clocking Out: Recent Trends in Working Hours, Policy Brief" (2004) <www.oecd.org>.

${ }^{2}$ New Zealand Department of Labour "Work-Life Balance in New Zealand: A Snapshot of employee and employer attitudes and experiences" (2006) <www.dol.govt.nz>.

${ }^{3}$ L Fursman "Working Long Hours in New Zealand: A Profile of Long Hours Workers Using Data from the 2006 Census" (2008) New Zealand Department of Labour <www.dol.govt.nz>.

${ }^{4}$ Statistics New Zealand Survey of Working Life March 2008 Quarter (2008) at 19.
} 
bargaining and restrictions on working time embodied in statute and regulation) in terms of allowing workers to limit and control their time working time.

As a preliminary, it is necessary to define BI. One definition is that it is "an income unconditionally granted to all on an individual basis without means test or work requirement." radical but it is an idea with a long lineage and it is a concept that has been the subject of much discussion internationally ${ }^{6}$ in recent times. ${ }^{7}$ A variety of ways of structuring this entitlement have been proposed, but most fall under one of two categories: the Basic Income or the Negative Income Tax. Advocates propose that it should be set at a level sufficient to sustain "a modest but decent standard of living". ${ }^{8}$ The idea has been raised in New Zealand, ${ }^{9}$ most recently in Gareth Morgan's "Big Kahuna" proposal that everybody should get a basic income of $\$ 10,000$ regardless of whether they are employed or not. ${ }^{10}$

The article is structured in three parts: in the first section the main legal mechanisms for controlling work time are located within a historical context, in the second section it is suggested that the emergence of postFordist work patterns and the subsequent growth in precarious work and the increasing participation of women in the paid workforce make these mechanisms less effective than previously. In the second and final section, the suggestion is made that a BI could be a more effective and flexible mechanism than current law of allowing workers to limit their working time. In particular, it is suggested that a BI could be a better alternative in terms of allowing individuals to regain control of their time by virtue of:

1) The bargaining power a BI would confer on individuals in their working lives.

2) The options a BI might provide with regard to the distribution of reproductive work.

3) The enhanced ability a BI would potentially confer to participate in the wider political sphere.

The legal mechanisms for controlling work time in New Zealand are now located in their historical context. Following that, they are critiqued within the present day context which is characterised by firstly postFordist work patterns and an associated growth in precarious work and secondly increased participation of women in the paid workforce.

\section{A Brief History of Time and Law}

In pre-industrial times "reproductive" work, that is the work of caring for dependants and the physical needs of a household, and "productive work," which is market work, were not separate conceptually, geographically or temporally. ${ }^{11}$ To a great extent, the rhythm of work varied according to natural time cycles (day, season, life).

In New Zealand, prior to colonial contact, the Māori concept of time was rooted in Māori cosmology. Traditional beliefs delineated three periods of time from which emerged man beginning with Te Kore i.e. the nothingness. This was a necessary period of chaos where order was neither evident nor required, from there Te Po, which was an evolution from nothingness into darkness. This was, in turn, followed by the broad

\footnotetext{
${ }^{5}$ This is the definition adopted by the Basic Income Earth Network <http//www.basicincome.org/bien/>.

${ }^{6}$ For example, see John Cunliffe and Guido Erreygers (eds) The Origins of Universal Grants: an Anthology of Historical Writings on Basic Capital and Basic Income (Palgrave Macmillan, Basingstoke, 2004).

${ }^{7}$ For a bibliography containing more than 2000 books and articles relating to a guaranteed basic income see the US Basic Income Network: Bibliography <http://www.usbig.net/bib.html>

${ }^{8}$ Carole Pateman "Freedom and Democratisation: Why Basic Income is to be Preferred to Basic Capital" in K Dowding, J De Wispelaar and S White (eds) The Ethics of Stakeholding (Palgrave MacMillan, London England, 2003).

${ }^{9}$ M Goldsmith "Universal Basic Income and the Concept of Citizenship" (1997)9 Social Policy Journal 45; K Rankin "Revisiting the UBI" (1998) 7(2) New Zealand Political Review 12.

${ }^{10}$ Gareth Morgan "What to Watch Out for in 2010" New Zealand Listener (New Zealand, 6 February 2010).

${ }^{11}$ See J Williams "From Difference to Dominance to Domesticity: Care as Work, Gender as Tradition" (2001) 76 Chicago Kent

Law Review 1441 at 1443.
} 
daylight of Te A Marama. Associated with this cosmology the Māori sense of time and the Māori way of life and work ethic is rooted in lunar cycles and the growing periods of plants and the fertility cycles of fish and mammals. Time in a Māori sense is not necessarily chronological. Its measurement is established by the meaning of related events rather than the period between events with periods of birth and death requiring specific responses according to tribal lore and tradition. ${ }^{12}$

However, Enlightenment thinking posited humans as ecologically distinct from the natural world and as a consequence time perceptions, in Western culture, became "increasingly mechanised in both physical and conceptual representation". ${ }^{13}$ This process of mechanisation of time was continued and exacerbated with the advent of the industrial revolution where the transition to Industrial Capitalism and wage labour imposed work patterns characterised by regularity. Thompson describes this as movement from task orientation to timed work as the labouring classes were forced to assume new time compliant working habits. ${ }^{14}$ In conjunction with this, productive work and reproductive work begin to be conceived as separately gendered activities. As certain types of production were time disciplined, and moved into factories, they were gendered masculine. Other types of production (such as production of food and clothing) were coded as "caring" rather than "work" and were gendered feminine. ${ }^{15}$

This transition was not an instantaneous one. Thompson states "in the first stage we find simple resistance. But in the next stage, as the new time discipline is imposed so the workers begin to fight not against time but about it." ${ }^{16}$ Thus, for much of the nineteenth century, working time was a central focus of political and legal struggle. ${ }^{17}$ This struggle resulted in the implementation of a number of measures aimed at shaping time for the benefit of workers and, in particular restricting work hours.

Although there were aspects unique to New Zealand's particular cultural mix and history, the local mechanisms that evolved to regulate time were similar to those which evolved internationally, i.e. customary norms, norms derived from collective bargaining which operate alongside standardised limits on the working day/week/year or limits on working hours embodied in statute and regulations. ${ }^{18}$ The nature of these protections can best be illustrated by a brief overview of how they operated historically in New Zealand:

Samuel Parnell, as mentioned above, is credited with being the driving force behind the introduction of the eight hour day to New Zealand. This norm was perhaps less than ideally enforced by means of a dunking in Wellington Harbour for any who worked longer than eight hours but subsequently, albeit informally, the eight hour day became the standard working day. To the present day, relatively informal workplace norms play a role in limiting working time and may in some circumstances be given legal recognition and enforced by the courts. ${ }^{19}$

Unions have historically also been very important in terms of negotiating and enforcing limits on the hours workers could be required to work. For example, in 1936, the Industrial Conciliation and Arbitration Act required that the Court of Arbitration should fix at not more than 40 the maximum number of hours,

\footnotetext{
${ }^{12}$ Gail Whitford and Mike Barnes "Te Ao Hurihuri New Zealand's First Time in W Pental and A Harvey et al (eds) Time Use Research in Social Science (Springer, New York, 1999) 212 at 214.

${ }^{13}$ Ibid at 216.

${ }^{14}$ EP Thompson Customs in Common: Studies in Traditional Popular Culture (Merlin Press, London, 1991) at 383.

${ }^{15}$ See Williams, above $\mathrm{n} 11$, at 1443.

${ }^{16}$ Thompson, above n 14, at 388).

${ }^{17}$ J Conaghan "Time to Dream? Flexibility, Families, and the Regulation of Working Time" in J Fudge and R Owens (eds) Precarious Work, Women, and the New Economy (Hart Publishing, Oxford, 2006) 101 at 111.

${ }^{18}$ For discussion of international developments see G Bosch "Working Time: Tendencies and Emerging Issues (1999) 138 “ International Labour Review 135; Conaghan, above n 17, 102.

${ }^{19}$ NZ Amalgamated Engineering Printing and Manufacturing Union Inc v The Christchurch Press, A Division of Fairfax New Zealand Ltd [2005]1 ERNZ 288 is an example of where the courts gave formal legal recognition to an informal work custom and did not allow Christchurch press to require employees to work longer night shifts as this would be contrary to a custom of 30 years standing.
} 
exclusive of overtime, to be worked in any one week by any worker bound by the award (i.e. union negotiated agreements concerning terms and conditions of employment). With this, the 40-hour five-day week became almost universal at least for a time.

Statutory protections are another key legal mechanism that has evolved to control and restrict working time. In New Zealand, perhaps more than other countries, collectivisation and union negotiated awards were historically the central source of these protections. ${ }^{20}$ However, in more recent years statutory protections restricting working time have become more significant. ${ }^{21}$

It is important to note that the protective mechanisms described above have never benefited all workers. As well as serving a protective purpose, labour and employment law has a gate keeping function; it provides rights to some workers and then it limits access to those rights. In general, the legal status of "employee" is an important prerequisite to accessing rights to statutory protection and the right to legally strike or collectively bargain. ${ }^{22}$ Those who cannot fit themselves within the definition of employee, such as the selfemployed cannot access these rights. ${ }^{23}$ Furthermore, in New Zealand unions have, at least historically, generally operated for the benefit of union members, i.e. predominantly male full-time breadwinners rather than for the benefit of all workers. ${ }^{24}$

For a long time, however, the legal mechanisms for regulating time were, if not perfect, arguably good enough in terms of outcome for a majority of workers in New Zealand. However, two critical changes in organisation and distribution of work have emerged over the past years which make these mechanisms increasingly less effective at allowing workers to control their time. These are:

a) The trend towards post-Fordist patterns of production and the corresponding rise in precarious work

b) The increasing participation of women in paid work

\section{The Trends towards Post-Fordist patterns of production}

Post-Fordism, as the next stage after Industrial Capitalism, entails a different mode of production: one that is more flexible and specialised, where employers respond to market conditions by retaining a core of skilled employees supplemented on an as-needed basis by a periphery of less secure workers who may be part-time, short term contract or casual employees together with subcontractors, agency temps and the self-employed who provide flexibility. In New Zealand, as elsewhere, ${ }^{25}$ a growing number of workers now find themselves in what is known as precarious or contingent work, i.e. jobs characterised by insecurity, low wages, and few benefits. ${ }^{26}$ These jobs are also characterised by variable hours that can make day-to-day time management and long-term planning extremely problematic.

\footnotetext{
${ }^{20}$ For example, historically, there was no statutory right to sick leave until a three day entitlement was mandated by Section 30 of the Holidays Amendment Act 1991. Nonetheless, most workers would effectively have had a right to sick leave by virtue of the applicable union negotiated award. M Wilson "The Employment Relations Act: A Framework for a Fairer way" in E Rassmussen (ed) Employment Relationships: New Zealand's Employment Relations Act (Auckland University Press, Auckland, 2004$) 9$ at 11.

${ }^{21}$ Some examples are s 11 of the Minimum Wages 1983; The Parental Leave and Employment Protection Act 1987; the Holidays Act 2003; the Employment Relations (Flexible Working Arrangements Amendment Act 2007; the Employment Relations (Rest Breaks, Infant feeding and Other Matters) Amendment Act 2009.

22 These rights which are established by the Employment Relations Act 2000 are only available to employees who fall within the definition of s 6 .

${ }^{23}$ For example under the Holidays Act 2003, only employees are entitled to at least four weeks paid annual holidays a year. Similarly for employees, there is a minimum provision of five days' paid sick leave after the first six months of continuous employment.

${ }^{24}$ For some historical discussion see S Robertson "Women Workers and the New Zealand Arbitration Court" (1991) 61 Labour History 30 .

${ }^{25}$ J Fudge and R Owens (eds) Precarious Work, Women, and the New Economy (Hart Publishing, Oxford, 2006).

${ }^{26}$ D Tucker "Precarious Non-Standard Employment- A Review of the Literature" (2002) New Zealand Department of Labour at $66<w w w . d o l . g o v t . n z>$.
} 
Data on the extent of precarious work in New Zealand is thin however, the number is not insignificant with one study suggesting that at least one third of New Zealand employees are in non-standard jobs. ${ }^{27}$ Such workers are frequently un-unionised, ${ }^{28}$ have low awareness of any legal rights they may have ${ }^{29}$ and limited ability to use legal processes to resolve employment related disputes. ${ }^{30}$

While existing legal mechanisms for limiting working time may work adequately for employees in secure, long-term permanent employment, they are necessarily less effective for those on the low paid, casualised periphery of the workforce who are either not entitled to legal rights due to their legal status, ${ }^{31}$ or not in a position to enforce the rights they are theoretically entitled to. Mechanisms which limit working time pertaining to the status of employee are also not accessible to the self-employed and here it should be noted that New Zealand has relatively high levels of self-employment. ${ }^{32}$

Customary norms have in the past operated as a mechanism for controlling and restricting work time, whether formally or informally enforced. However, such norms can only develop in work sites populated by permanent, long-term employees. They are a product of stability and ongoing association between workers and employers. Long standing customs concerning limitation of working hours can neither develop nor be enforced in workplaces staffed by transient, casualised workers.

Collective bargaining, too, is problematic as a means of controlling working hours. The substantial decline in union membership that began in the 1990s has not been reversed. Although the Employment Relations Act 2000 has the stated objective of promoting collective bargaining, ${ }^{33}$ collective bargaining is at an historic low, ${ }^{34}$ and union membership is particularly low in sectors where the incidence of casual and temporary employment is high. ${ }^{35}$ While the union movement is making commendable efforts to extend the benefits of collective bargaining to these excluded workers, ${ }^{36}$ it must be said that the grim scenario regarding union membership in New Zealand reflects world wide trends of falling union membership. The reasons are complex but the fact that workers tend to be more transient and insecure, and workplaces and jobs more fluid in a post-Fordist environment as opposed to under industrial capitalism does not make organisation of unions easy. ${ }^{37}$ All things considered, failing some other drastic intervention, collective bargaining, for most workers, cannot be seen as a mechanism to rely on in terms of restricting working hours in the current conditions.

\footnotetext{
${ }^{27}$ C Allan and others "From Standard to Non Standard Employment: Labour Force Change in Australia, New Zealand and South Africa" (2001) 22 International Journal of Manpower 735.

${ }^{28}$ Tucker, above n 26, at 49.

${ }^{29}$ Ibid, at 45.

${ }^{30}$ New Zealand Department of Labour "Casual and Temporary Employment: Report on Phase One Research" (2007) <www.dol.govt.nz>.

${ }^{31}$ The self-employed are generally unable to access statutory rights to time away from work. However, employees in precarious, short-term, irregular work may also not be able to access statutory protection. For example, under the Holidays Act 2003, there is a minimum provision of five days paid sick leave after the first six months of continuous employment. The Employment Relations (Flexible Working Arrangements) Amendment Act 2007 provides certain employees with a statutory right to request a variation of their working arrangements, including hours of work and days of work if they are responsible for the care of any person. However, as with sick leave this is only an option after six months of continuous employment).

${ }^{32}$ A recent survey reports that, of the people employed in the March 2008 quarter, $12 \%$ were self-employed and not employing others. Statistics New Zealand, above $n 4$.

${ }^{33}$ Employment Relations Act 2000, s 3(a)(iii).

${ }^{34}$ In 1990, public sector bargaining density was $97 \%$ and private sector density $48 \%$. In 2009, public sector density is $49 \%$ and private sector density is 9\%: Stephen Blumenfeld, Peter Ryall and Graeme Kiely Employment Agreements: Bargaining Trends and Employment Law Update 2008/2009 (Victoria University of Wellington Industrial Relations Centre 2008/2009) at 14.

${ }^{35}$ New Zealand Department of Labour, above n 30, at 12.

${ }^{36}$ For New Zealand Council of Trade Unions proposals for legal and union change to improve the availability of collective bargaining to currently unionised, marginalised workers see Helen Kelly "Union Change" (paper presented to Unions Creating Alternatives Biennial Conference, October 2009).

${ }^{37}$ For discussion of the problems facing unions in the new working environment engendered by post-Fordism see Katherine Stone From Widgets to Digits: Employment Regulation for the Changing Workplace (Cambridge University Press, Cambridge, 2004) 196.
} 
Statutory protection of working hours tied to the status of employee is also problematic in the more precarious working environment engendered under post-Fordist norms. Increasing numbers of workers do not fit the legal criteria of employee as workplaces are organised along more flexible lines. ${ }^{38}$ This problem is exacerbated by the fact that some employers camouflage employees as contractors to cut costs by circumventing the statutory protections employees are entitled to. Even those workers who may theoretically be entitled to the rights pertaining to employees will frequently not have the backing of a union to assist in enforcing these rights.

All in all, the trends towards post-Fordist working patterns leave increasing numbers of workers unable to access legal mechanisms which limit working time. The problem of difficulty in accessing legal protection of time is compounded by the fact that more and more New Zealand women now work in the paid workforce which puts greater time pressure on individuals and families. This point is now discussed in greater depth.

\section{The Increasing Participation of Women in Paid Workforce}

While there is no doubt that, in general, collective bargaining and statutory control of work time historically succeeded in reducing working hours or at least contributed towards shaping them in accordance with workers desires, they are not unproblematic. Supiot suggests that the legal regulation of time reinforced an idea of time as an objective commodity capable of regulation. Effectively, this ratified "the economic fiction that work is detachable from the worker" and it effectively created a false dichotomy between working time and free time. ${ }^{39}$ The distinction between working time and free time is, however, artificial. Even though reproductive work occurs in so-called free time, it is essential that it occurs for the worker to take his or her place in the workforce. Indeed paid work is parasitic on reproductive work. Most obviously, if one is to be productive in the workforce, washing will have to be done, meals prepared and eaten, and health (both emotional and physical) maintained. Dependants, young and old, must also be cared for.

Under the model of industrial capitalism, the apparent dichotomy between work and free time resulted in reproductive work being unvalued and invisible. There was no need to take reproductive work into account in work design and time regulation as it was invisibly taken care of elsewhere. This distinction, while problematic in many respects, ${ }^{40}$ was perhaps tenable under historic social norms. These were predicated on a "gender contract" whereby women took care of the reproductive work in return for men assuming the breadwinner role. ${ }^{41}$

However, reproductive work and paid work can no longer be treated as dichotomised worlds where never the twain shall meet. For a variety of reasons, increasing numbers of women have joined the paid workforce. In New Zealand in 1959, approximately $29 \%$ of working age women participated in the job market. By contrast in March 2008, the female participation rate was $61.7 \% .^{42}$ Reproductive work still needs to be done

\footnotetext{
${ }^{38}$ The legal concept of employee is widely viewed as problematic in the new working environment. For discussion see H Collins "Independent Contractors and the Challenge of Vertical Disintegration to Employment Protection Laws" (1990) Oxford Journal of Legal Studies 10; J Conaghan "Labour Law and 'New Economy' Discourse” (2003)16 Australian Journal of Labour Law 9; B Creighton "Employment Security and Atypical Work in Australia" (1994-1995) Comparative Labor Law Journal 16; P Spoonley "Is Non Standard Work becoming Standard? Trends and Issues" (2004) NZJER 29; G Standing, "The Australian Charter of Employment Rights: the Missing Dimensions" (2008) JIR 355.

${ }^{39}$ Alain Supiot Beyond Employment: Changes in Work and the Future of Labour Law in Europe (Oxford University Press, Oxford, 2001) 64.

${ }^{40}$ See generally M Waring If Women Counted: A New Feminist Economics (Harper Collins, San Francisco, 1988); J Williams Unbending Gender (Oxford University Press, New York, 2000).

${ }^{41}$ See Judy Fudge "A New Gender Contract? Work/Life Balance and Working Time Flexibility in J Conaghan and K Rittich (eds) Labour Law, Work and Family (Oxford University Press, Oxford England, 2005) at 261 for discussion of this concept and its evolution.

${ }^{42}$ New Zealand Department of Labour "Female Labour Market Fact Sheet" (2008) <www.dol.govt.nz>.
} 
but with more women involved in the workforce, there is no longer an invisible unpaid workforce standing ready to undertake this. Increasingly, it must be fitted in around paid work. Inevitably, there is less time in which to carry it out, which creates time pressure on individuals and families.

New Zealand has introduced some positive initiatives to attempt to manage the intrusion of the needs of reproductive life onto working life and no doubt these have helped some women and families. ${ }^{43}$ However, these concessions largely remain the preserve of employees, i.e. those already privileged in permanent positions who have the confidence to ask employers for them. They do little for those at the periphery of the workforce, i.e. the struggling self-employed, or the casual on-call non-unionised worker hoping to be offered enough work to make the rent. For example, at present, new mothers who can establish that they have worked a certain number of hours for the same employer in the immediate preceding 12 months are entitled to 52 weeks of unpaid extended leave. ${ }^{44}$ The precarious worker is likely to struggle to meet the necessary criteria of having worked a minimum hours for the same employer in the immediate preceding 12 months; and for the low waged or the self-employed individual trying to get a business of the ground, taking a year off work may not be remotely financial feasible.

It thus seems that the legal mechanisms of informal norms, collective bargaining and statutory right tied to the status of employee are not sufficiently addressing the issues of work and time. Arguably, this is because they are rooted in increasingly obsolete work patterns premised on strong unions, a workforce of permanent full employees, supported by an unpaid female workforce who carried the burden of reproductive work and caring for dependents. These mechanisms have been undermined by de-unionisation, the emergence of precarious work and the growing numbers of workers unable to access the protections pertaining to employees as well as by the growing numbers of women in the workplace.

It is possible that ways might be sought to reinvent existing mechanisms for controlling time and to somehow extend statutory protection and collective bargaining to those workers who are currently excluded. ${ }^{4546}$ However, here a more radical option is explored and a question is posed: Could a BI be a better option?

\section{Would BI be a Better Option?}

In this section it is suggested that a BI could be a better, more flexible alternative to existing labour and employment law mechanisms in terms of allowing individuals to regain control of their time in the new working environment by virtue of:

1) The bargaining power a BI would confer on individuals in their working lives.

2) The options a BI might provide with regard to the distribution of reproductive work.

3) The enhanced ability a BI would potentially confer to participate in the wider political sphere.

\section{Bargaining Power}

The idea of flexibility and variation in working time is not a bad thing. The primal, pre-industrial rhythms of seasons and of birth, life and death are still inherent to human life despite the more recent overlays of the work patterns and the rules associated, firstly, with industrial capitalism and latterly post-Fordism. The reality is that the patterns of rural working time, following seasonal imperatives, are different from those of

\footnotetext{
43 i.e The Parental Leave and Employment Protection Act 1987; the Holidays Act 2003; the Employment Relations (Flexible Working Arrangements Amendment Act 2007; the Employment Relations (Rest Breaks, Infant feeding and Other Matters) Amendment Act 2009.

${ }^{44}$ The Parental Leave and Employment Protection Act 1987

${ }^{45}$ The extension of paid parental leave to the self-employed under the Paid Parental Leave Act is an example where this occurred.

${ }^{46}$ See for example the ideas discussed in Helen Kelly "Union Change" (paper presented to Unions Creating Alternatives Biennial Conference, October 2009).
} 
urban commuters or to the patterns of caregivers of babies and small children. At various life stages people may have different preferences as to how they wish to organise their working time; parents with young children require a different life rhythm to that of a collective of late-night jazz musicians. Overly rigid time regulation such as a hypothetical law or a union negotiated contractual term requiring everyone to down tools at 5pm cannot take account of the varying needs of different institutional settings and of different lives. $^{47}$

As long as there is ample freedom to choose and to move between rhythms of life, arguably individuals and the community are better served by encouraging diversity and freedom of choice rather than by enforcing repressive conformity to one constructed time. What is important is that the ideal of flexibility is not permitted to operate solely for the benefit of employers or the powerful driven solely by the needs of production. What is needed by workers is bargaining power. Historically, informal norms, unions and statutory regulation provided this to a majority of workers but, as has been suggested above, too many workers are, in real terms, unable to access these provisions in the new working environment.

If, however, a BI sufficient to live on at a modest yet decent standard was available as of right, regardless of participation in the labour market, then exiting the labour market would become a viable option for workers. 48 A worker with a guaranteed BI who needs to negotiate reduced hours or more flexible hours or more regular hours or time away from work is inherently in a stronger bargaining position than one who is solely dependent on their wage for the support of themselves and their families.

A BI also has the benefit of assisting not just employees as existing legal mechanisms predominantly do, but potentially also those who are not employees to manage their time in accordance with their own particular needs and wishes. For example, a struggling small self-employed dairy owner in receipt of a BI would, should she choose, be able to close up her shop and take a day off safe in the knowledge that her ability to pay that weeks rent would not be compromised. Hence, the evidential and legal difficulties surrounding the shoehorning into, or the exclusion of workers from, the category of employee could be circumvented as the ability to control ones working time becomes the right of all workers.

A BI will also have the advantage of a being a mechanism that will most often more easily allow for individualised negotiations and solutions crafted to suit individual circumstances than any general law could hope to be. While not a return to a pre-industrial lifestyle, a BI would make it more possible for individuals to live their lives in ways in keeping with the rhythms of the seasons. It could also potentially create spaces for individuals to respond appropriately to significant events such as birth and death rather than such events having to be fitted into a timeframe constructed around the demands of the workplace and the imperative of financially supporting oneself and one's dependents

A further advantage of a BI is that it has the advantage of improving the likelihood of compliance with any specific law that seeks to limit work hours for particular public policy or safety reasons. Legal limitations of working hours are of no use if individuals do not have the power to insist on compliance. A restriction on the number of continuous hours a truck driver can drive without a rest stop is meaningless if the truck driver is un-unionised, vulnerable and financially dependent on an unscrupulous employer who does not care about the law. Studies have shown that those in precarious, insecure jobs tend to risk their health and safety in order to maintain good relationships with their employers. ${ }^{49}$ The same individual in receipt of a BI has the power to walk away from unsatisfactory, unsafe arrangements or to insist on the need for adherence to the letter of the law.

\footnotetext{
${ }^{47}$ Todd Rackoff A Time for Every Purpose: Law and the Balance of Life (Harvard University Press, Cambridge, 2002 ) at 163.

${ }^{48}$ On the potential of a Basic Income to enhance bargaining power by securing the ability to exit the labour market place see $\mathrm{R}$ Jubb "Basic Income, Republican Freedom, and Effective Market Power" (2008) 3(2) Basic Income Studies 4.

${ }^{49}$ P Spoonley "Is Non Standard Work becoming Standard? Trends and Issues" (2004) NZJER 29.
} 


\section{Addressing the Issue of Reproductive Work}

A solution addressing the problem of lack of time for workers must take into account the reproductive work which underpins participation in the paid workforce. Existing legal mechanisms attempted to address these but they are limited in their ability to address the varied needs of workers and families. For example, the Holidays Act 2003 provides that, for most employees, there is a minimum provision of five days sick leave after the first six months of continuous employment. This may be a generous allowance for a single healthy adult but for a solo parent responsible for a child with serious health problems, five days would be woefully inadequate. The point is that family and individual circumstances are subject to vast variation and it is hard to see how any law could adequately accommodate this.

By contrast, a BI could be a very useful means of enabling individuals and families to manage the essential reproductive work which underpins participation in paid work in a flexible way that genuinely takes account of each family's and each individual's actual needs and desires. ${ }^{50}$ If set at a high enough level, a BI would make reducing to part-time work or periods away from the paid workforce a practical option for money and time pressed individuals or families without driving them into poverty.

Finally, for some families and individuals, a BI might enable some greater redistribution of some reproductive work such as child care and meal preparation, to the market. While not all such work is capable of commodification the option of being able to commodify some of it could reduce time pressure on many families.

\section{Political Power}

Thus far, discussion of the legal mechanisms designed to limit working time has focused primarily on the direct controls on individual working relationships. In fact, this is not the only mechanism available to control working time. Legal regulation of time outside individual work relationships is also an option.

Supiot suggests that while it is important to allow for the possibilities of diversity, creativity, and the possibility of social experimentation, there are larger societal interests at stake in the regulation of working time, so it should not be entirely determined by negotiations between individuals. ${ }^{51} \mathrm{He}$ expresses this concern because he is concerned that fragmentation of time may come at a cost to communal time. ${ }^{52}$ Civic involvement is a collective endeavour. Individuals not only need leisure time in which to become involved, but they need shared leisure time, that is, similarly co-ordinated schedules. With all its faults, the regulated working time associated with earlier industrial collectivism gives a sort of collective tempo to life. For example, after-work socialising could be expected to occur in the evening as the majority were understood to be employed 9 to 5 . Under a more individualised and subjective system of apportioning working time, there is a danger that time devoted to all forms of social and civic life, already under pressure, will be squeezed even further as everyone struggles with different schedules.

One possibility which would limit work time is the introduction of more statutory public holidays. ${ }^{53}$ Indeed, if the goal is purely to limit working time it would be theoretically possible to impose draconian legal

\footnotetext{
${ }^{50}$ For an overview of the various strands in Basic Income literature on the effect of a BI on the distribution of reproductive work see I Robeyns "Introduction: Revisiting the Feminism and Basic Income Debate" (2008)3(3) Basic Income Studies 1.

${ }^{51}$ Alain Supiot Beyond Employment: Changes in Work and the Future of Labour Law in Europe (Oxford University Press, Oxford, 2001) 93.

${ }^{52}$ Ibid, at 90.

${ }^{53}$ For example, in New Zealand, there has been some discussion about creating a mid-winter public holiday celebrating Matariki which is the time at which the Pleiades star cluster is visible and which traditionally established the correct time to plant crops.
} 
measures such as the compulsory enforced closing of all businesses, shopping malls, libraries, swimming pools and other public facilities on Sunday. The question would then become whether this would really be a genuine quality of life improvement and whether rigidly enforced time norms such as these are fair to people who, for whatever personal reasons, want to, for example, work 80 hour weeks or keep their business open over the weekend?

Law alone cannot resolve such questions. The issues are complex and there are many competing interests. What is required is discussion and debate in the wider political sphere. ${ }^{54}$ However, a prerequisite of participation in such discourse is the time in which to do so; too little free time results in disempowerment and civic disengagement. ${ }^{55}$ Overworked and overtired workers will struggle to participate in any political dialogue about time, yet theirs are the voices that most need to be heard.

A mechanism is needed for ensuring that the demands of work are not permitted to crowd out the right and opportunity to participate politically in the dialogue surrounding time norms. Could a BI provide such a mechanism? Arguably, a BI could potentially enhance participation in social and political life as it will be possible, at least for those who wish it, to reduce working hours somewhat so that fitting in such activity around working life will no longer require heroic efforts. ${ }^{56}{ }^{57}$ As such, a BI would seem to be a mechanism ideally suited to enabling workers to take part in the political processes and dialogues that will shape the time norms that they will live by both now and in the future.

\section{Conclusion}

Time, work and law are intimately connected. As the organisation of work changes, the tools for limiting working time must change and evolve. In this article it has been argued that just as a transition occurred from pre-industrial working patterns to industrial working patterns, new working patterns that existing legal mechanisms are not adjusting adequately to are also emerging. The poorest working people are working the longest hours and unable to access the protections that the law purports to provide. The result of this is that improving individuals' ability to limit their work time is an issue that needs to be addressed. It has been suggested that BI could be a better method of achieving this than existing legal mechanisms: A BI would be a more flexible way than law to empower individuals to manage their working time in ways that takes account of the varying needs of both different institutional settings and of different life stages; a BI also offers more promise than law as a way of allowing individuals to negotiate how to manage the reproductive work that underpins paid work; a BI would also potentially allow otherwise time pressed individuals to take part in the political discourses surrounding the development and implementation of any agreed on communal time norms.

All that said, it must be conceded that while there is some interest in the idea of a BI in New Zealand it is not a concept likely to be taken seriously in the current political environment. Of the political parties currently represented in Parliament, only the minority Green Party have expressed openness to the concept. Their stated policy is that they "support... a full and wide ranging public debate on...[BI]". ${ }^{58}$ New Zealand does, however, have a history of innovation and progressiveness; for example, it was the first country in the world to introduce women's suffrage, the eight hour day and to legalise collective bargaining, so a time may come when the arguments presented here might be seriously entertained.

\footnotetext{
54 Todd Rackoff A Time for Every Purpose: Law and the Balance of Life (Harvard University Press, Cambridge, 2002$) 183$.

${ }^{55}$ Ibid, at $47-48$.

${ }^{56}$ This point is frequently argued in Basic Income literature. For example, see Carole Pateman "Freedom and Democratisation: Why Basic Income is to be Preferred to Basic Capital" in K Dowding, J de Wispelaar and S White (eds) the Ethics of Stakeholding (Palgrave MacMillan, London, 2003) 15.

${ }^{57}$ For a recent work on the possibilities of linking basic income to participation in civil and political society see Guy Standing Work After Globalization: Building Occupational Citizenship (Edward Elgar, Cheltenham, 2009)

${ }^{58}$ Sue Bradford Income Support Policy (Green Party of Aotearoa New Zealand 2008)

<http://www.greens.org.nz/policy/incomesupport>
} 
Reproduced with permission of the copyright owner. Further reproduction prohibited without permission. 